\title{
Autonomia, avaluació i cultura de centre
}

\author{
Mario González Jorge \\ Departament de Pedagogia de la URV al Campus Terres de l'Ebre \\ Director de l'Escola Remolins, Tortosa \\ mario.gonzalez@urv.cat
}

Resum

Lautonomia, en els centres educatius, no tan sols depèn del marc normatiu que la regula, sinó que s'hi exerceix en funció de la capacitat que tenen les institucions per explotar totes les possibilitats en l'adaptació del context escolar a les necessitats de la seva comunitat. I, tot i que la norma reguladora és la mateixa, les circumstàncies intrínseques $i$ les de l'entorn, conjuntament amb les dinàmiques de cada centre, determinaran el grau d'autonomia real que acabarà desenvolupant cada centre educatiu.

Paraules clau: autonomia, avaluació, cultura de centre, projecte educatiu de centre, projecte de direcció.

\section{Abstract}

The autonomy of educational centres depends not only on legislation but also on the capacity of the institutions to adapt the school context to the needs of the community they serve. And, although the legislation is the same for everyone, the intrinsic circumstances and those of the environment, in conjunction with the dynamics of each school, will determine the real extent of the autonomy of each educational centre.

Key words: autonomy, evaluation, school culture, educational project, management project.

\section{Introducció}

Per desenvolupar una tasca, i per fer-la bé, cal que coincideixin diversos factors. Si no és així, algunes feines es duen a terme amb un cert grau d'imperfecció o indefinició, o bé no responen a les demandes ni a les expectatives que havien generat.

Especialment cal disposar dels instruments més adequats per perfeccionar cada fase del procés fins al seu acabament. Ara bé, també és fonamental que se sàpiguen posar en funcionament aquestes eines de forma correcta i se n'aprofitin al màxim totes les potencialitats. Cal que els instruments els administrin mans amb una certa expertesa i que les habilitats professionals els posin a rodar per tal d'aconseguir el resultat desitjat.

Aquest plantejament genèric també és aplicable al món educatiu. De fet, no hauríem de perdre de vista que és l'educació allò que ha de preparar els individus per conviure, i no a l'inrevés. Pel que fa l'autonomia en l'àmbit escolar, ja tenim l'eina. El Decret 102/2010, de 3 d'agost, d'autonomia dels centres educatius és l'instrument amb què ens hem dotat, per tal de fer més assumibles els objectius educatius que pretenem. I, sense voler-ne valorar les característiques, hem de tenir present que l'autonomia és fruit d'una llarga demanda collectiva per poder fer la millor adequació educativa a les característiques de cada context escolar. En general, els objectius del sistema educatiu s'han definit en termes de millora del rendiment acadèmic i millora de la 
cohesió social. Tot i que podríem interpretar que hi poden haver altres prioritats, probablement també podríem vincular-les a aquests dos principis generals - a aquests principis, ara no m'hi referiré, però no podem obviar que tenen una importantíssima responsabilitat en el desplegament de l'autonomia dels centres.

Però fem una parada!

-Autonomia per a què?

- Autonomia per decidir.

-Decidir què?

- Decidir la capacitat d'actuació en els centres.

-De quins marges d'actuació parlem?

-Dels que delimita la pròpia normativa i dels que es deriven de cada Projecte educatiu de centre.

-En quins àmbits decidirem?

-En el pedagògic, en l'organitzatiu i en el de la gestió de recursos humans i materials.

La clau, però, és en el com! La regulació dels marges d'autonomia dels centres docents ha reforçat la centralitat del Projecte educatiu de centre i fa que sigui la peça clau del desenvolupament institucional de l'escola. Tant és així que, tot i apostar per un lideratge fort de les direccions i distribuir-los-el, supedita el Projecte de direcció al desplegament i aplicació del Projecte educatiu per al període del mandat. Amb tot, permet que el propi Projecte de direcció contingui les propostes i els elements necessaris per revisar el Projecte educatiu. Com veiem, doncs, és un encaix d'imbricacions mútues que precisament haurien de permetre un exercici d'autonomia per afavorir un major grau en l'assoliment dels objectius educatius. Ara bé, fent un símil marítim, no sempre es preveu l'arribada a bon port de manera tan directa si hi ha mar de fons en la navegació. I en molts centres educatius hi ha una certa remor acompanyada de marees altes i baixes. També és cert, però, que sovint les tempestes vénen seguides de calma i bona pesca.

Lautonomia pedagògica i organitzativa dels currículums és allò que permet les concrecions necessàries per donar resposta a les especificitats de cada comunitat escolar, sense perdre de vista la necessària garantia en l'assoliment de les competències bàsiques i en el desenvolupament dels principis rectors d'excel.lència i equitat. Estem parlant, alhora, d'universalitat i de diversitat, per poder donar cabuda al concepte de singularitat de cada centre. I aquí hi entren, en joc, un conjunt de possibilitats, pel que fa a l'ús del temps i l'espai, a l'atenció a la diversitat de l'alumnat, a l'assignació del professorat, a l'adaptació del currículum, a la innovació pedagògica i a la definició d'estratègies pròpies de cada centre.

Lautonomia organitzativa ha de recollir el conjunt d'acords i decisions sobre les normes d'organització i funcionament del centre, i també ha d'estar al servei del desenvolupament del Projecte educatiu. Estableix els criteris d'organització pedagògica, pel que fa a l'agrupament dels alumnes, a la formació dels equips docents, als mecanismes de coordinació, a l’atenció a la diversitat, a l'alumnat amb NEE, als mecanismes d'actuació educativa globalitzada i als mecanismes d'acció i coordinació tutorial. També especifica els òrgans i procediments de participació, i recull les mesures de promoció de la convivència $i$ les mesures correctores i sancionadores.

Lautonomia en la gestió de personal determina qui forma els òrgans unipersonals de direcció i els addicionals, defineix l'equip directiu, el consell de direcció, les tutories i la seva assignació, les coordinacions docents i els òrgans col-legiats de participació en el control i la gestió, així com la composició i funcionament. Tot i que és l’administració educativa qui estableix les plantilles i els llocs de treball docent, les direccions poden formular les propostes sobre la definició dels llocs de treball que s'hagin assignat al centre -en especial, pel que fa als requisits de titulació i capacitació professional- i també poden proposar llocs docents amb un perfil singular, d'acord amb el Projecte educatiu, així com els llocs d'especial responsabilitat que donen suport als òrgans de govern per poder desenvolupar el Projecte educatiu i per aplicar el Projecte de direcció. També es contempla el nomenament de personal interí substitut d'una borsa de treball, d'acord amb els criteris que determini l'administració.

La gestió -econòmica, de serveis i de recursos materials - recau sobre el director del centre; aquesta gestió s'ajusta als principis de la legisla- 
ció general i reinterpreta l'ús social dels centres, tot establint-ne els criteris, els requisits i els procediments.

Ara bé, aquesta nova assignació i aquest traspàs de funcions comporten que l'equip directiu serà avaluat pels resultats en la gestió del personal i haurà de preparar propostes per a la seva millora, adequant l'estructura i l'organització per garantir l'assoliment dels objectius. En aquest sentit, s'assigna a la direcció el control de la jornada laboral, la resolució sobre les faltes d'assistència i/o puntualitat no justificades, la imposició de sancions disciplinàries per les faltes lleus $\mathrm{i}$ la proposta d'incoar expedients disciplinaris per faltes greus o molt greus.

Se suposa que tot aquest conjunt d'eines - novament «eines»- posat en mans experimentades hauria de permetre retre comptes dels resultats obtinguts en l'exercici de l'autonomia.

Però el decret d'autonomia ¿podria haver estat "el decret d'autonomia i avaluació"? Rotundament, sí, i és que el desplegament de l'autonomia dels centres va indissolublement acompanyat de la seva corresponent avaluació, amb la intenció última de contribuir a millorar la qualitat del servei i a assolir les competències bàsiques de l'alumnat. De fet, aquesta nova norma deroga l'Ordre de 20 d'octubre de 1997 per la qual es regula l'avaluació del centres docents sostinguts amb fons públics, que fou vigent fins que es publicà el Decret d'autonomia dels centres.

I el subjecte actiu que ha de propiciar els mecanismes d'aquesta avaluació recau fonamentalment en la inspecció d'educació, d'acord amb l'Agència d'Avaluació i Prospectiva de l'Educació. També hi poden participar els ens locals.

Però, si l'avaluació - tal com es proposa- ha de tenir en compte necessàriament els indicadors de progrés recollits en el Projecte educatiu, caldrà anar incorporant inexcusablement, a aquests projectes, els indicadors de resultats, de processos, de recursos i de contextos, cap dels quals no ha format part de la nostra cultura professional. En tot cas, es preveu una avaluació del rendiment educatiu que tingui presents les pràctiques de tipus inclusiu, les avaluacions de les competències bàsiques, el resultat de les avaluacions externes i les dades relatives al context socioeducatiu i a l'abandonament escolar. Per tant, sembla adient entendre que una veritable avaluació objectiva de cada realitat escolar ha de comptar amb un recull de dades quantitatives que es complementin amb dades qualitatives que matisin les possibilitats en l'exercici de l'autonomia i que expliquin les característiques contextuals de l'entorn i del centre.

En qualsevol cas, s'atribueix un caràcter continu i cíclic a les avaluacions dels centres, que han de coincidir amb la finalització dels mandats de direcció.

I per què i per a què avaluar? Perquè l'avaluació també és una altra de les eines a les quals ens hem referit anteriorment. I cal saber posar en funcionament aquest mecanisme que aporta informació, sobre la situació escolar, amb la màxima objectivitat possible, quan s'empra de manera rigorosa. Especialment, també, perquè l'autonomia suposa un reforç de les direccions dels centres, i precisament seran aquestes les que, específicament, se sotmetran a l'avaluació de l'exercici de les funcions directives, conjuntament amb l'avaluació del professorat en l'exercici de la funció docent. Del resultat positiu, en aquestes valoracions, se'n dedueix l'adquisició de graus docents i elements de promoció professional docent per al professorat, i mèrits en la carrera professional docent per als directors. A més, de l'avaluació, se’n desprenen efectes que serviran per revisar el Projecte educatiu, les concrecions del currículum, la documentació general del centre i, específicament, el Projecte de direcció. També hauria de: incidir en l'eventual substitució de les persones que exerceixen els òrgans unipersonals de govern i coordinació; permetre revisar, quan convingués, l'acord de coresponsabilitat i els recursos addicionals assignats al centre; possibilitar obtenir la qualificació de centre de referència educativa; orientar la formació permanent i d'actualització del professorat; aportar criteris per revisar el Projecte de direcció, i valorar l'exercici professional del personal d'atenció educativa.

Però la norma no canvia la realitat escolar. Cal aplicar-la en contextos concrets, en escoles, en instituts, en institucions... que formen part del Servei d'Educació de Catalunya. I aquests 
centres ja tenen unes dinàmiques, unes maneres consolidades o unes formes de relació i treball que progressivament s'han admès com a habituals i que poden entrar en contradicció amb la nova proposta normativa. I és aquí on sorgeixen els reptes, els dubtes i les oportunitats.

Exercir l'autonomia significa autodefinir la institució escolar dintre del marc normatiu. És per això que permet singularitzar cada centre a mig camí entre la universalitat de contextos educatius i la diversitat de formes d'organització.

En aquest sentit, val la pena promoure el dinamisme de la cultura del centre com a motor de la seva autonomia. Cal consolidar les bones pràctiques educatives i adoptar nous models d'eficàcia en l'assoliment de les fites, i nous models d'eficiència en la gestió dels recursos, tot adaptant-los al context.

I, com que les institucions educatives també són diverses $\mathrm{i}$ amb dinàmiques molt diferenciades, no podem saber si la cultura pròpia de cada centre podrà alentir el desenvolupament de la seva comunitat educativa $\mathrm{o}$, per contra, podrà ser una altra d'aquelles eines que cal aprofitar per posar en marxa el progrés de la institució.

En qualsevol cas, sempre podríem trobar opcions contraposades que, de vegades, es plantegen amb intenció de negar la necessitat del canvi i perpetuar, així, l'ordre ja establert. I ens preguntem: què és més convenient: promoure l'autonomia pedagògica, organitzativa i de gestió per afavorir un canvi en la cultura de centre, o permetre que la cultura imperant a l'escola sigui allò que determini els marges dautonomia que ens atorgarem? Dubtem sobre si la comunitat educativa sabrà tenir una veu majoritària i comuna $\mathrm{o}$, per contra, generarà divergències en el com $\mathrm{i}$ el quan caldrà exercir l'autonomia traspassada. No tenim clar si existeix de debò una cultura de centre o si, precisament aquesta cultura, ha estat el marge d'autonomia sobre què hem fet progressar la institució escolar. I respecte de l'autonomia en si, què permet, en major mesura, l'intervencionisme o la flexibilitat? Ah!, potser depèn de la cultura imperant en cada centre... En última instància, reflexionem sobre si també s'han traspassat implícitament, als centres, en la regulació de la seva autonomia, tasques i funcions per assignar, conjuntament, nous mecanismes d'avaluació i descentralització, etc. Aquests són paranys conceptuals per evitar el canvi, que, d'altra ban$\mathrm{da}$, considerem necessari. Sigui en un sentit o un altre, més a poc a poc o més de pressa, el canvi es produirà.

A tall de conclusió, voldria manifestar que estic satisfet que s'hagi regulat l'autonomia dels centres i que espero el moment en què s'apliqui aquesta norma, que sembla que, en regular els centres públics i concertats, reforça el concepte de l'educació com a servei públic; que proposa un lideratge fort en les direccions dels centres educatius, però que supedita el desplegament del Projecte de direcció a les concrecions del Projecte educatiu per al període de temps durant el qual governi la direcció; que pressuposa la conveniència que l'administració s’adapti a les necessitats del centre - i no a l'inrevés-; que atorga un paper rellevant a l'avaluació, en funció dels resultats, amb certa independència dels processos, i que té en compte el context per consolidar un model d'eficàcia i eficiència educativa.

\section{Bibliografia}

Generalitat de Catalunya. "Decret 102/2010, de 3 d'agost, d'autonomia dels centres educatius". DOGC [Barcelona, 0508-2010], núm. 5686, pàg. 61485. [També consultable a: <http://www.gencat.cat/diari/5686/10209099.htm>.] 